\title{
RHIZOBACTERIA ABLE TO PRODUCE PHYTOTOXIC METABOLITES
}

\author{
Daniel D. C. Carvalho ${ }^{3}$; Denilson F. Oliveira ${ }^{1 *}$; Rogério S. B. Corrêa ${ }^{2}$; Vicente P. Campos ${ }^{3}$; Renato M. Guimarães²; \\ João L. Coimbra ${ }^{3}$
}

\begin{abstract}
${ }^{1}$ Departamento de Química, Universidade Federal de Lavras, Lavras, MG, Brasil; ${ }^{2}$ Departamento de Agricultura, Universidade Federal de Lavras, Lavras, MG, Brasil; ${ }^{3}$ Departamento de Fitopatologia, Universidade Federal de Lavras, Lavras, MG, Brasil
\end{abstract}

Submitted: April 18, 2007; Returned to authors for corrections: October 04, 2007; Approved: November 15, 2007.

\begin{abstract}
To contribute for the development of environmental friendly methods for weed control, a selection of rhizobacteria able to produce phytotoxic substances was carried out. Initially, 35 strains previously isolated from plants in the south of Minas Gerais State (Brazil) were grown in tryptic soy broth. After removal of bacterial cells, the resulting liquids were freeze-dried and extracted with methanol/ethyl acetate (1:1). The extracts were concentrated under vacuum and dissolved in water to be submitted to a lettuce (Lactuca sativa L.) seed assay. Metabolites produced by five strains reduced the number of normal seedlings to values statistically bellow the one observed for the negative control, being the most expressive results obtained with Bacillus cereus Frankland and Frankland, isolated from Ricinus communis L., which was able to cause rotted rootlets to $82.4 \%$ of seedlings. The bacterium metabolites also avoided germination of $52 \%$ Brachiaria decumbens Stapf seeds and the remaining $48 \%$ resulted in abnormal seedlings. Metabolites from B. cereus were submitted to a purification process guided by the lettuce seed assay. As a consequence, one substance causing rotted rootlets to all lettuce seedlings during the seed assay at $0.057 \mathrm{~g} / \mathrm{L}$ was isolated and will be identified in future studies.
\end{abstract}

Key words: Bacillus cereus, bioherbicide, Lactuca sativa, phytotoxin, rhizobacteria, Brachiaria decumbens

\section{INTRODUCTION}

Weed control is so important for agriculture that $40-60 \%$ of all worldwide commercialized agrochemicals correspond to herbicides. Although these substances are essential to obtain the necessary food and fiber, they also present some negative aspects as the increase of cost production and the contamination of human beings and the environment with toxic residues $(13,23,24)$. Consequently, methodologies less expensive and toxic to control weed are greatly welcome. Apparently such a problem can be solved by the use of rhizobacteria, which may affect the development of plants with a magnitude as large as the one observed for phytopathogenic bacteria (20). As an example it is possible to mention the use of Pseudomonas putida (Trevisan) Migula, Stenotrophomonas maltophilia Palleroni and Bradbury and Enterobacter taylorae Hormaeche and Edwards to control Bromus tectorum L. in wheat fields (22), or the application of Pseudomonas spp. in corn fields to control Striga hermonthica (Del.) Benth. (1).

As it has been observed that rhizobacteria can act against plants by the production of phytotoxic substances like cyanide (2), indole-3-acetic acid (21) and haterumalide A (12), a simple method to identify rhizobacteria potentially useful for weed control could consist on submitting their metabolites to an assay with lettuce seed (Lactuca sativa L.), which has been described as an excellent phytotoxin detector (31). Thus, this work was aimed to use this assay to select phytotoxin producing rhizobacteria to be employed in future studies directed to the development of new methods for weed control.

*Corresponding Author. Mailing address: Universidade Federal de Lavras, Departamento de Química, Campus Universitário, CxP 3037, Lavras-MG, 37200-000, Brasil. Tel.: (55) (35) 3829-1623, Fax: (55) (35) 3829-1271. E-mail: denilson@ufla.br 


\section{MATERIALS AND METHODS}

\section{Production of rhizobacterial metabolites}

Rhizobacteria used in this study are on deposit at the Department of Plant Pathology - Federal University of Lavras, State of Minas Gerais, Brazil. They were previously isolated from roots of signalgrass (Brachiaria sp.), coffee (Coffea arabica L.), okra (Hibiscus esculentus L.), indian cress (Tropaeolum majus L.), tomato (Lycopersicon esculentum Mill.), marigold (Tagetes erecta L.), castorbean (Ricinus communis L.), pigeonpea (Cajanus cajan L.), common bean (Phaseolus vulgaris $\mathrm{L}$.), corn (Zea mays L.) and lettuce (Lactuca sativa L.) by Coimbra (8), who identified the microorganisms by fatty acid methyl esters analysis, which were carried as described elsewhere $(7,19)$. They were grown on tryptic soy agar (TSA Merck KgaA) during two days, at $28^{\circ} \mathrm{C}$, and transferred to tryptic soy broth culture medium (TSB - Isofar Indústria e Comércio de Produtos Químicos). After ten days at $28^{\circ} \mathrm{C}$, under constant stirring $(100 \mathrm{cpm})$, bacterial cells were removed by centrifugation $(10,000 \mathrm{~g})$ and $70 \mathrm{~mL}$ of each supernatant liquid were freezedried. To each resulting residue were added $14 \mathrm{~mL}$ of a methanol/ ethyl acetate $(\mathrm{MeOH} / \mathrm{AcOEt} ; 1: 1)$ solution and the mixture obtained was filtered through cotton. The filtrates were concentrated to dryness in a rotary evaporator and dissolved in distilled water $(70 \mathrm{~mL})$ to be submitted to the lettuce seed assay.

\section{Lettuce seed assay}

Fifty (twenty five when pure substance was assayed) lettuce seeds (Lactuca sativa L. cv. Salad Bowl) were disposed in a transparent plastic box (GERBOX - $11.4 \times 11.4 \mathrm{~cm}$ ) containing two sheets of germination paper $(10.5 \times 10.5 \mathrm{~cm})$ embedding an amount of sample to be evaluated equivalent to 2.5 times their weight. After incubation at $20^{\circ} \mathrm{C}$ under a $12 \mathrm{~h}$ photoperiod, during seven days, the following parameters were used to evaluate the experiment: non-germinated seeds and seedlings with rotted rootlets (6). As negative controls distilled water and/or TSB extract obtained as described for rhizobacteria supernatant liquids were employed. Aqueous solutions of glyphosate at $6.85 \mathrm{mg} / \mathrm{L}, 17.14 \mathrm{mg} / \mathrm{L}$ and $34.28 \mathrm{mg} / \mathrm{L}$, which were prepared by dissolving in water Agrisato $480 \mathrm{CS}$, produced by Alkagro do Brasil Ltda, were used as positive controls. The experiment was carried out with four replicates, in a randomized design. Results were directly submitted to analysis of variance, and average values were compared by Scott-Knott (27) calculations $(\mathrm{P} \leq 0.05)$. Statistical analyses were done using SISVAR software (11).

\section{Signalgrass seed assay}

Seeds of signalgrass (Brachiaria decumbens Stapf), produced by Sempra Sementes Ltda (Brazil), were soaked in concentrated sulfuric acid during $15 \mathrm{~min}$ and washed with water
(6). Then, they were employed in an assay adapted from the lettuce seed assay described above for the crude rhizobacteria metabolites. Temperature was changed to $35^{\circ} \mathrm{C}$ during the exposure to light and to $25^{\circ} \mathrm{C}$ during the remaining period. The following parameters were used to evaluate the experiment: up to the fifth day non-germinated seeds and abnormal seedlings (with rotted rootlets, inexistent root, shoots shorter than $1.4 \mathrm{~cm}$ or without leaves) (6).

\section{Purification of Bacillus cereus Frankland and Frankland metabolites}

B. cereus was grown in TSA and some colonies were transferred to eight flasks containing $250 \mathrm{~mL}$ of TSB each. After 11 days at $25^{\circ} \mathrm{C}$, under constant stirring $(100 \mathrm{cpm})$, cells were removed by centrifugation $(10,000 \mathrm{~g})$ during $15 \mathrm{~min}$ and supernatant liquids were combined and freeze-dried. Part (0.69 g) of the resulting mass (39.33) was successively washed with $\operatorname{AcOEt}(2 \times 7 \mathrm{~mL})$ and $\mathrm{MeOH} / \mathrm{AcOEt}(1: 1 ; 2 \times 14 \mathrm{~mL})$. All fractions were concentrated under reduced pressure and dissolved in 35 $\mathrm{mL}$ of distilled water to be submitted to the lettuce assay.

Another part $(20 \mathrm{~g})$ of the freeze dried metabolites was washed with $\mathrm{AcOEt} / \mathrm{MeOH}(1: 1 ; 6 \times 100 \mathrm{~mL})$ and the liquid phase was concentrated under reduced pressure to dryness. It resulted in a residue $(7.52 \mathrm{~g})$ from which an aliquot $(1.0 \mathrm{~g})$ was taken and passed through a silica gel column $(2.3 \times 15.0$ $\mathrm{cm}$ ) with $\mathrm{AcOEt}, \mathrm{MeOH}, \mathrm{H}_{2} \mathrm{O}$ and $0.1 \mathrm{M} \mathrm{HCl}(200 \mathrm{~mL}$ of each). From the four new fractions samples amounting to $30 \%$ of their volume were removed, concentrated under reduced pressure, dissolved in $35 \mathrm{~mL}$ of $\mathrm{H}_{2} \mathrm{O}$ and submitted to the lettuce assay. The remaining (70\%) of the $\mathrm{MeOH}$ fraction was concentrated under reduced pressure to afford a residue $(0.514$ g) that was eluted through a silica gel column $(2.3 \times 8.0 \mathrm{~cm})$ with AcOEt/MeOH (50 mL, 9:1; $50 \mathrm{~mL}, 4: 1 ; 50 \mathrm{~mL}, 7: 3 ; 50 \mathrm{~mL}$, $3: 2 ; 50 \mathrm{~mL}, 1: 1), \mathrm{MeOH}(100 \mathrm{~mL}), \mathrm{H}_{2} \mathrm{O}(100 \mathrm{~mL})$ and $0.1 \mathrm{M} \mathrm{HCl}$ $(100 \mathrm{~mL})$. Samples corresponding to $40 \%$ of the resulting fractions were concentrated under reduced pressure and dissolved in $35 \mathrm{~mL} \mathrm{H}_{2} \mathrm{O}$ to be submitted to the lettuce assay. The remaining (60\%) of the $\mathrm{AcOEt} / \mathrm{MeOH}(9: 1)$ fraction was concentrated under reduced pressure to afford a residue $(0.004$ g) that was analyzed by thin layer chromatography (TLC) employing plastic plates coated with silica gel 60. AcOEt/ $\mathrm{MeOH}(9: 1)$ was used to elute the sample and spots were visualized with ultraviolet light, iodine vapor and ceric sulphate solution (3). Then, the residue $(0.004 \mathrm{~g})$ was passed through a silica gel column $(0.8 \mathrm{~cm} \times 15.0 \mathrm{~cm})$ with AcOEt/hexane $(100$ $\mathrm{mL}, 1: 1)$, AcOEt $(40 \mathrm{~mL})$ and $\mathrm{MeOH}(50 \mathrm{~mL})$. Fractions of $5 \mathrm{~mL}$ were collected and analyzed by TLC as described above. Five new fractions were obtained by combination of fractions 1-2, 3-16, 17-19, AcOEt and MeOH. Samples amounting to 50\% of each of them were concentrated under low pressure and dissolved in $35 \mathrm{~mL}$ of $\mathrm{H}_{2} \mathrm{O}$ to be submitted to the lettuce seed assay. The remaining of the AcOEt fraction was concentrated 
under low pressure to afford a white solid weighting $0.002 \mathrm{~g}$. It was analyzed by TLC as described before, employing AcOEt/ hexane (1:1) as eluent.

A simplified scheme of the procedures employed in the purification steps is presented on Fig. 1.

\section{RESULTS}

Among the 35 rhizobacteria strains studied, only the metabolites produced by Bacillus cereus, B. pumillus (strain 55-30), Enterobacter asburiae, E. cloacae (strain 54-10) and Microbacterium liquefaciens afforded numbers of normal seedlings statistically bellow those observed for TSB and water, which were the negative controls (Table 1). The phytotoxic effects were observed mainly on the rootlets, whose size were smaller than those obtained for healthy seedlings and usually presented rotted regions.

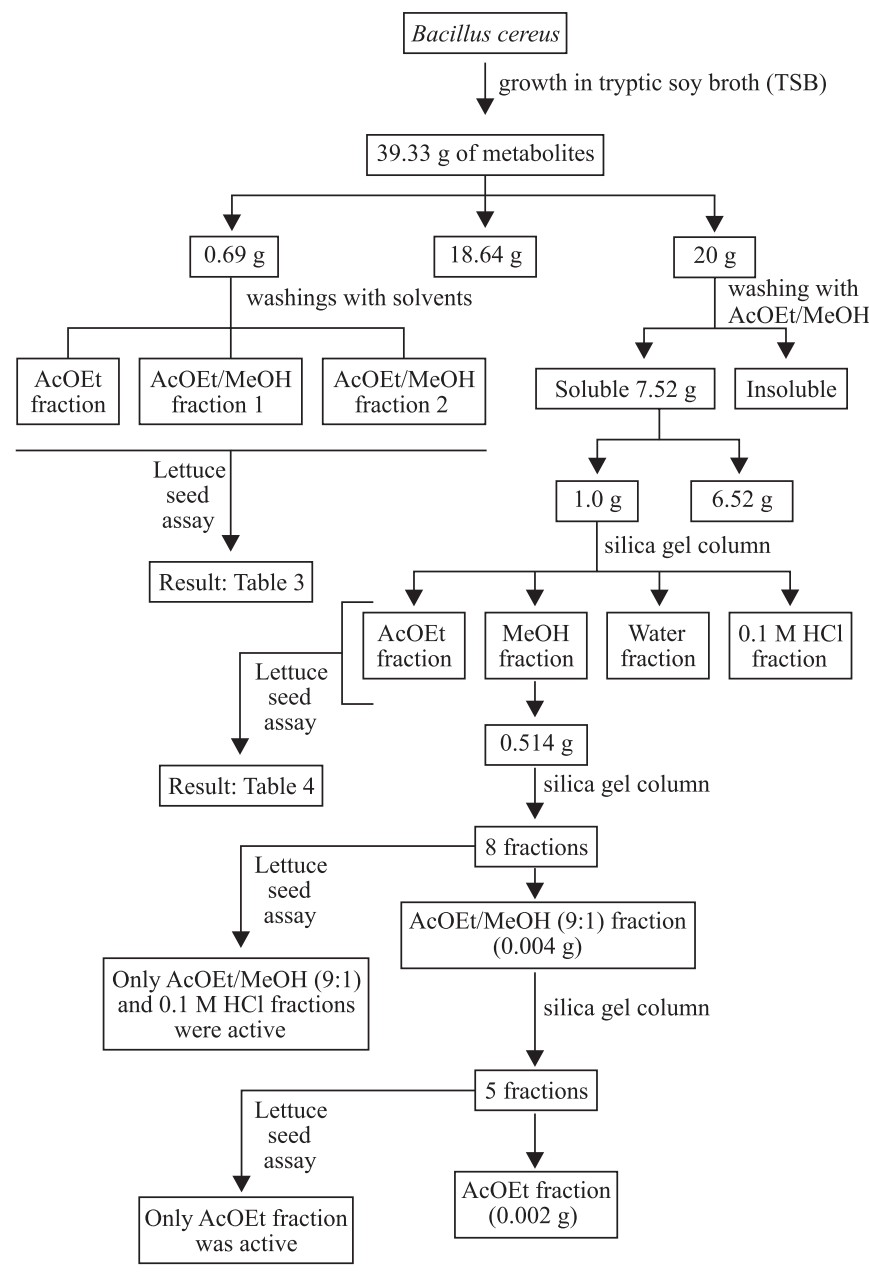

Figure 1. Simplified scheme of the Bacillus cereus metabolites purification.
As the most expressive results were observed for the metabolites produced by $B$. cereus, isolated from Ricinus communis, they were also used against Brachiaria decumbens seeds. The number of healthy seedlings was considerably reduced (Table 2 ).

When crude $B$. cereus metabolites were submitted to small scale solvent washings, it was observed that AcOEt could not dissolve the active substance produced by that bacterium (Table 3). Thus, it was necessary to employ mixtures of such solvent and $\mathrm{MeOH}$ to extract the phytotoxic metabolite.

During the first chromatographic process, only those fractions eluted with $\mathrm{MeOH}$ and $0.1 \mathrm{M} \mathrm{HCl}$ presented toxic effects to lettuce seeds. Actually, no seed exposed to them could germinate (Table 4).

When the $\mathrm{MeOH}$ fraction (Table 4) was submitted to a new chromatographic process, eight new fractions were obtained (AcOEt/MeOH 9:1; 4:1; 7:3; 3:2; $1: 1, \mathrm{MeOH}, \mathrm{H}_{2} \mathrm{O}$ and $0.1 \mathrm{M}$ $\mathrm{HCl}$ ), among which the most active was the one eluted with AcOEt/MeOH (9:1) that caused rotted rootlets to $98 \%$ of seedlings. It was also observed that the fraction eluted with 0.1 $\mathrm{M} \mathrm{HCl}$ presented a very weak phytotoxic effect, while all the other fractions were inactive against lettuce seeds.

During the last purification step, which was carried out by a chromatographic fractionation of the AcOEt/MeOH (9:1) fraction, only the material eluted with AcOEt was active. It caused rotted rootlets to $93 \%$ of seedlings. When analyzed by TLC, only one homogenous spot could be observed for the solid resulting from such fraction.

\section{DISCUSSION}

Although metabolites produced by five rhizobacteria strains have presented phytotoxic activity during the lettuce seed assay, only Bacillus cereus afforded really expressive values (Table 1). The other four microorganisms metabolites presented results very near to the negative controls (TSB and water). Such behavior is in accordance with the work by Karadeniz et al. (16), who found out that B. cereus could produce indole-3acetic acid, giberelic acid, zeatin and abscisic acid when grown in brain heart broth. All these substances are plant growth hormones, whose effect on plant usually varies with their concentrations (26).

The literature reveals that Bacilus pumillus can be used in bioherbicide formulations (14). However, only strain 55-30 presented some activity against lettuce seeds (Table 1). Perhaps that is a consequence of indole-3-acetic acid production, since Kang et al. (15) have observed that such bacterium is able to synthesize this substance in tryptophan-amended medium.

Although Bacillus megaterium is able to inhibit Ipomoea hederacea Jacq. growth through the production of phytotoxins $(16,17)$, its metabolites presented no effect on lettuce (Table 1). A possible explanation for these results could rely on the AcOEt 
Table 1. Effect of rhizobacteria crude metabolites on lettuce seeds.

\begin{tabular}{|c|c|c|c|}
\hline Rhizobacteria & Plant source & $\begin{array}{l}\text { Normal } \\
\text { seedlings }\end{array}$ & $\begin{array}{l}\text { Non-germinated } \\
\text { seeds } s^{1,2}\end{array}$ \\
\hline Agrisato $480 \mathrm{CS}$ (concentration 01$)^{3}$ & & $45.5 b$ & $1.5 \mathrm{a}$ \\
\hline Agrisato $480 \mathrm{CS}$ (concentration 03$)^{5}$ & & 0a & $2.0 \mathrm{a}$ \\
\hline \multicolumn{4}{|l|}{ Bacillus cereus Frankland and } \\
\hline Frankland $(\text { strain } 57-02)^{6}$ & Ricinus communis L. & $0 \mathrm{a}$ & $8.7 \mathrm{c}$ \\
\hline B. megaterium $($ strain 55-16) & Hibiscus esculentus L. & $46.0 \mathrm{~d}$ & $1.7 \mathrm{a}$ \\
\hline B. megaterium $($ strain $55-21)$ & Coffea arabica $\mathrm{L}$. & $48.0 \mathrm{e}$ & $1.5 \mathrm{a}$ \\
\hline Bacillus pumillus Meyer and Gottheil (strain 54-08) & Trapaeolum majus L. & $49.3 \mathrm{e}$ & $0.2 \mathrm{a}$ \\
\hline B. pumillus (strain 54-23) & Hibiscus esculentus L. & $46.3 \mathrm{~d}$ & $2.5 \mathrm{a}$ \\
\hline B. pumillus (strain 55-13) & Coffea arabica $\mathrm{L}$. & $49.3 \mathrm{e}$ & $0.7 \mathrm{a}$ \\
\hline B. pumillus (strain 55-30) & Lycopersicon esculentum Mill. & $42.6 \mathrm{c}$ & $5.2 \mathrm{~b}$ \\
\hline B. pumillus (strain 83-11) & Zea mays L. & $48.1 \mathrm{e}$ & $0.7 \mathrm{a}$ \\
\hline B. pumillus (strain 83-16) & Zea mays L. & 48.1e & $1.7 \mathrm{a}$ \\
\hline B. pumillus (strain 83-17) & Zea mays L. & $47.8 \mathrm{e}$ & $1.2 \mathrm{a}$ \\
\hline B. pumillus (strain 83-18) & Lycopersicon esculentum Mill. & $46.5 d$ & $2.5 \mathrm{a}$ \\
\hline B. pumillus (strain 84-27) & Brachiaria sp. & 46.1d & $1.2 \mathrm{a}$ \\
\hline Bacillus sphaericus Meyer and Neide (Strain 62-18) & Lactuca sativa $\mathrm{L}$. & $49.0 \mathrm{e}$ & $0.5 \mathrm{a}$ \\
\hline Bacillus thurigiensis Berliner (strain 84-12) & Brachiaria sp. & $46.6 \mathrm{~d}$ & $1.2 \mathrm{a}$ \\
\hline B. thurigiensis (strain 55-15) & Tagetes sp. & $47.8 \mathrm{e}$ & $1.0 \mathrm{a}$ \\
\hline B. thurigiensis (strain 57-25) & Phaseolus vulgaris L. & 47.1d & $2.2 \mathrm{a}$ \\
\hline Enterobacter asburiae Brenner et al. (strain 62-04) & Lactuca sativa $\mathrm{L}$. & $40.3 \mathrm{~b}$ & $6.0 \mathrm{~b}$ \\
\hline $\begin{array}{c}\text { Enterobacter cloacae Hormaeche and } \\
\text { Edwards (strain 54-01) }\end{array}$ & Coffea arabica $\mathrm{L}$. & $47.0 \mathrm{~d}$ & $3.0 \mathrm{a}$ \\
\hline $\begin{array}{c}\text { Enterobacter hormaechei Hormaeche and } \\
\text { Edwards (strain 62-01) }\end{array}$ & Lactuca sativa $\mathrm{L}$. & $46.6 \mathrm{~d}$ & $1.7 \mathrm{a}$ \\
\hline \multicolumn{4}{|l|}{ Klebsiella planticola Bagley, Seidler and } \\
\hline Brenner (strain 56-29) & Lycopersicon esculentum Mill. & $46.0 \mathrm{~d}$ & $1.0 \mathrm{a}$ \\
\hline $\begin{array}{c}\text { Klebsiella pneumoniae (Schroeter) } \\
\text { Trevisan (strain 57-15) }\end{array}$ & Cajanus cajan L. & $45.8 \mathrm{~d}$ & $2.2 \mathrm{a}$ \\
\hline Kluyvera cryocrescens Farmer et al. & Trapaeolum majus L. & $47.1 d$ & $2.2 \mathrm{a}$ \\
\hline Microbacterium liquefaciens Takeuchi and Hatano & Coffea arabica $\mathrm{L}$. & $39.0 \mathrm{~b}$ & $6.2 b$ \\
\hline Paenibacillus macerans Ash et al. (strain 62-12) & Lactuca sativa $\mathrm{L}$. & $49.0 \mathrm{e}$ & $0.7 \mathrm{a}$ \\
\hline $\begin{array}{c}\text { Stenotrophomonas maltophilia } \\
\text { Palleroni and Bradbury }\end{array}$ & Lycopersicon esculentum Mill. & $45.6 \mathrm{~d}$ & $3.2 \mathrm{a}$ \\
\hline $\mathrm{TSB}^{7}$ & & $45.0 \mathrm{~d}$ & $2.0 \mathrm{a}$ \\
\hline Water & & $45.3 d$ & $4.0 \mathrm{~b}$ \\
\hline
\end{tabular}

${ }^{1}$ Average values after seven days at $20^{\circ} \mathrm{C} ;{ }^{2}$ Values with the same letter in each column do not differ from each other statistically according to Scott and Knott (27) calculations at $5 \%$ probability; ${ }^{3} 6.85 \mathrm{mg}$ of glyphosate/L; ${ }^{4} 17.14 \mathrm{mg}$ of glyphosate/L; ${ }^{5} 34.28 \mathrm{mg}$ of glyphosate/L; ${ }^{6} \mathrm{Necrosis}$ on roots; ${ }^{7}$ after freeze drying and extraction. 
Table 2. Effect of Bacillus cereus crude metabolites on Brachiaria decumbens seeds.

\begin{tabular}{ccc}
\hline Treatments & $\begin{array}{c}\text { Abnormal } \\
\text { seedlings }^{1,2}\end{array}$ & $\begin{array}{c}\text { Non-germinated } \\
\text { seeds }^{1}\end{array}$ \\
\hline B. cereus metabolites & $24.0 \mathrm{~b}$ & $26.0 \mathrm{a}$ \\
TSB $^{3}$ & $09.2 \mathrm{a}$ & $23.7 \mathrm{a}$ \\
Water & $10.0 \mathrm{a}$ & $24.2 \mathrm{a}$ \\
\hline
\end{tabular}

${ }^{1}$ Means of four replicates with the same letter in a column do not differ significantly $(P \leq 0.05)$ according to the Scott-Knott (27) calculations; ${ }^{2}$ Normal plantlets average height was $2.8 \mathrm{~cm} ;{ }^{3} \mathrm{After}$ extraction with $\mathrm{AcOEt} / \mathrm{MeOH}$ (1:1).

Table 3. Effect on lettuce seeds of fractions obtained during the small scale washings of the Bacillus cereus crude metabolites.

\begin{tabular}{ccc}
\hline Fractions $^{1}$ & $\begin{array}{c}\text { seedlings with } \\
\text { rotted rootlets }^{2}\end{array}$ & $\begin{array}{c}\text { non-germinated } \\
\text { seeds }^{2}\end{array}$ \\
\hline AcOEt & $07 \mathrm{a}$ & $00 \mathrm{a}$ \\
$\mathrm{AcOEt} / \mathrm{MeOH} 1$ & $70 \mathrm{c}$ & $30 \mathrm{~b}$ \\
$\mathrm{AcOEt} / \mathrm{MeOH} 2$ & $31 \mathrm{~b}$ & $69 \mathrm{c}$ \\
Water (control) & $02 \mathrm{a}$ & $01 \mathrm{a}$ \\
\hline
\end{tabular}

${ }^{1} \mathrm{AcOEt}$ (ethyl acetate); $\mathrm{MeOH}$ (methanol); ${ }^{2} \mathrm{Means}$ of four replicates with the same letter in a column do not differ significantly $(P \leq 0.05)$ according to the Scott-Knott (27) calculations.

Table 4. Effect on lettuce seeds of fractions obtained during the first chromatographic fractionation of the Bacillus cereus metabolites.

\begin{tabular}{ccc}
\hline Fractions $^{1}$ & $\begin{array}{c}\text { seedlings with } \\
\text { rotted rootlets }^{2}\end{array}$ & $\begin{array}{c}\text { non-germinated } \\
\text { seeds }^{2}\end{array}$ \\
\hline $\mathrm{AcOEt}$ & $06 \mathrm{a}$ & $02 \mathrm{a}$ \\
$\mathrm{MeOH}$ & $01 \mathrm{a}$ & $99 \mathrm{~b}$ \\
Water (fraction) & $09 \mathrm{a}$ & $05 \mathrm{a}$ \\
$0.1 \mathrm{MHCl}$ & $00 \mathrm{a}$ & $100 \mathrm{~b}$ \\
Water (control) & $07 \mathrm{a}$ & $02 \mathrm{a}$ \\
\hline
\end{tabular}

${ }^{1} \mathrm{AcOEt}$ (ethyl acetate); $\mathrm{MeOH}$ (methanol); ${ }^{2} \mathrm{Means}$ of four replicates with the same letter in a column do not differ significantly $(P \leq 0.05)$ according to the Scott-Knott (27) calculations.

lack of capability for dissolving some substances (28). Perhaps, B. megaterium had produced phytotoxic metabolites in TSB medium that could not be dissolved in $\mathrm{AcOEt} / \mathrm{MeOH}$ and, consequently, did not get in contact with lettuce seeds. To circumvent such possible problem, in a preliminary work AcOEt was completely substituted with $\mathrm{MeOH}$, which possesses an increased capacity to dissolve different substances (28). However, the results were not satisfactory because the TSB $\mathrm{MeOH}$ extract, which was one of the negative controls, considerably affected lettuce.

Although Enterobacter hormaechei presented no activity, the only strain of Enterobacter asburiae reported here and Enterobacter cloacae (strain 54-10) affected lettuce in a very low extension (Table 1). The last bacterium can produce the plant growth regulators phenylacetic acid, indole-3-acetic acid and tyrosol in liquid media (29), while the ability of the other two microorganisms to produce phytotoxic substances is unknown. It is also worth of mention that Enterobacter intermedius Hormaeche \& Edwards can produce 3-methylthiopropanoic acid, which can affect weed seedling development (18), and that Enterobacter taylorae Hormaeche \& Edwards can suppress germination and seedling growth of Bromus tectorum L. (22).

Stenotrophomonas maltophilia can either be used as a plant growth promoter (4) and as Bromus tectorum L. germination and seedling growth suppressor in wheat fields (22). According to Park et al. (25) and Suckstorff and Berg (32), it is also able to produce 3-indole-acetic acid. Anyway, S. maltophilia presented no effect against lettuce (Table 1). Similarly, other plant growth promoting rhizobacteria, Kluyvera cryocrescens (34) and Kluyvera pneumoniae $(10,16)$, were inactive against lettuce seeds.

Concerning Bacillus sphaericus, B. thuringiensis, Paenibacillus macerans, Klebsiella planticola, K. cryocrescens and $M$. liquefaciens, the absence of phytotoxic activity for their metabolites (Table 1) seemed reasonable, since no report describing any deleterious effect of such bacteria on plant was found.

As B. cereus metabolites presented the most promising results during the lettuce seed assay, it was submitted to a test with seeds from Brachiaria decumbens, a weed that causes considerable losses in Brazilian coffee production (30). Although the number of germinated seeds did not differ statistically from the one observed for the negative control, no healthy seedlings could be obtained (Table 2). This result seems in accordance with Zaidi et al. (33) and Karadeniz et al. (16), who described the ability of Bacillus spp. to produce plant hormones, which can present deleterious effects on plants (26).

In order to contribute for the development of a new method for weed control employing $B$. cereus, a preliminary study was carried out to identify the metabolite active against $B$. decumbens. During the small scale solvent washings, the intermediate polarity of the active substance was evident, since AcOEt (5) could not dissolve it (Table 3, Fig. 1).

Surprisingly, when metabolites soluble in AcOEt/MeOH (1:1) were eluted through silica gel, two active fractions were obtained (Table 4, Fig. 1), indicating the production of at least two phytotoxins by $B$. cereus. When the $\mathrm{MeOH}$ fraction (Table 4) was submitted to another chromatographic process, eight new 
fractions were obtained, among which the AcOEt/MeOH (9:1) and $0.1 \mathrm{M} \mathrm{HCl}$ fractions presented deleterious effects on lettuce seeds. As it seems very probable that the active substance eluted with $\mathrm{MeOH}$ during the first chromatographic process would elute with $\mathrm{MeOH}$ or water during the following step (9), apparently the microorganism produced one substance that decomposed to another one, much more polar, which eluted with $0.1 \mathrm{M} \mathrm{HCl}$.

During the last fractionation on silica gel (Fig. 1), the only active fraction, eluted with AcOEt, seemed to correspond to a pure substance, since it presented a very homogeneous spot when analyzed by TLC (3). In the near future, such substance will be identified and produced in a large scale to be submitted to testes with $B$. decumbens to evaluate its potential to control this weed.

\section{ACKNOWLEDGEMENTS}

The authors thank FAPEMIG (Fundação de Amparo à Pesquisa do Estado de Minas Gerias) for a fellowship.

\section{RESUMO}

\section{Rizobactérias produtoras de substâncias fitotóxicas}

Com vistas a contribuir para o desenvolvimento de métodos não agressivos ao meio ambiente, para o controle de plantas invasoras, buscou-se selecionar rizobactérias produtoras de substâncias fitotóxicas. Inicialmente, 35 culturas previamente isoladas de plantas da região sul do Estado de Minas Gerais (Brasil) foram cultivadas em caldo soja tripticaseína. Após remoção das células bacterianas, os líquidos resultantes foram liofilizados e extraídos com metanol/acetato de etila (1:1). Os extratos foram concentrados sob vácuo e submetidos a testes com sementes de alface (Lactuca sativa L.). Os metabólitos produzidos por cinco isolados bacterianos reduziram o número de plântulas normais para valores estatisticamente inferiores aos observados para o controle negativo, sendo os mais expressivos resultados obtidos com Bacillus cereus Frankland and Frankland, isolado de Ricinus communis L., que causou necroses nas radículas de $82,4 \%$ das plântulas. Os metabólitos dessa bactéria também impediram a germinação de $52 \%$ das sementes de Brachiaria decumbens Stapf e fizeram com que as $48 \%$ restantes dessem origem a plântulas anormais. Os metabólitos de B. cereus foram submetidos a processos de purificação direcionados por testes com sementes de alface. Em decorrência, isolou-se uma substância, que será identificada em estudos futuros. Na concentração de $0,057 \mathrm{~g} / \mathrm{L}$, causou necrose nas radículas de todas as plântulas de alface provenientes do teste com sementes.

Palavras-chave: Bacillus cereus, bio-herbicida, Lactuca sativa, fitotoxina, rizobactéria, Brachiaria decumbens

\section{REFERENCES}

1. Ahonsi, M.O.; Berner, D.K.; Emechebe, A.M.; Lagoke, S.T. (2002). Selection of rhizobacterial strains for suppression of germination of Striga hermonthica (Del.) Benth. seeds. Biol. Control, 24, 142-152.

2. Alstrom, S.; Burns, R.G. (1989). Cyanide production by rhizobacteria as possible mechanism of plant growth inhibition. Biol. Fert. Soils, 7, 232.

3. Analabs. (1987). Chromatography chemicals and accessories. Norwalk, [s.n.]. 330p.

4. Banerjee, M.R.; Yesmin, L. (2003). New sulfur-oxidizing plant growth-promoting Rhizobacteria, e.g. RAY12 (Achromobacter piechaudii), RAY28 (Agrobacterium tumefaciens) or RAY132 (Stenotrophomonas maltophilia), useful for enhancing canola performance. W.O. Pat. 2003057861-A2. Jul. 17, 2003.

5. Berthod, A.; Deroux, J.M.; Bully, M. (1995). Liquid polarity and stationary-phase retention in countercurrent chromatography. In: Conway, W.D.; Petroski, R.J. (eds). Modern countercurrent chromatography. Am. Chem. Soc., Washington, p.16-34.

6. Brasil. (1992). Regras Para Análise de Sementes. Ministério de Agricultura, Brasília, 365p.

7. Chavarria-Carvajal, J.A.; Rodriguez-Kabana, R.; Kloepper, J.W.; Morgan-Jones, G. (2001). Changes in populations of microorganisms associated with organic amendments and benzaldehyde to control plant-parasitic nematodes. Nematropica, 31, 165-180.

8. Coimbra, J.L. (1998). Rizobactérias antagonistas a Meloidogyne javanica, isolamento e parasitismo de fungos de fêmeas de Meloidogyne spp. Lavras, 76 p. (Dissertação de mestrado. Universidade Federal de Lavras).

9. Collins, C.H.; Braga, G.L.; Bonato, P.S. (1997). Introdução a métodos cromatográficos. 7. ed. UNICAMP, Campinas, 279p.

10. Difuntorum-Tambalo, D.; Paterno, E.S.; Barraquio, W.; Duka, I.M. (2006). Identification of an indole-3-acetic acid-producing plant growth-promoting bacterium (PGPB) isolated from the roots of Centrosema pubescens Benth. Philipp. Agric. Scientist, 89, 149156.

11. Ferreira, D.F. (2000). Análises estatísticas por meio do Sisvar para Windows versão 4.0. XLV Reunião Anual da Região Brasileira da Sociedade Internacional de Biometria, São Carlos, p.255-258.

12. Gerhardson, B.; Thaning, C.; Weissmann, R.; Borowicz, J.; Welch, C.; Hedman, R. (2001). New bacterial isolate and its active metabolites, including new compound Haterumalide X, useful for controlling weeds and treating fungal diseases in plants, human and animals. S.E. Pat. 9904334-A. Jul. 26, 2001.

13. Hoagland, R.E. (1996). Chemical interactions with bioherbicides to improve efficiency. Weed Technol., 10, 651-674.

14. Japan Tobacco Inc. Control composition for Echinochloa crusgalli - contains microorganisms of genus Bacillus that are herbicidally active on Echinochloa crus-galli. J. P. Pat. 10017424-A. Jan. 20, 1998.

15. Kang, B.R.; Yang, K.Y.; Cho, B.H.; Han, T.H.; Kim, I.S.; Lee, M.C.; Anderson, A.J.; Kim, Y.C. (2006). Production of indole-3-acetic acid in the plant-beneficial strain Pseudomonas chlororaphis O6 is negatively regulated by the global sensor kinase GacS. Current Microbiol., 52, 473-476.

16. Karadeniz, A.; Topcuoglu, S.F.; Inan, S. (2006). Auxin, gibberellin, cytokinin and abscisic acid production in some bacteria. W. $J$. Microbiol. Biotechnol., 22, 1061-1064.

17. Kim, S.J.; Kremer, R.J. (2005). Scanning and transmission electron microscopy of root colonization of morningglory (Ipomoea spp.) seedlings by rhizobacteria. Symbiosis, 39, 117-124.

18. Kim, Y.C.; Kim, H.J.; Park, K.H.; Cho, J.Y.; Kim, K.Y.; Cho, B.K. (2003). 3-thylthiopropanoic acid produced by Enterobacter intermedium 60-2G inhibits fungal growth and weed seedling development. J. Antibiotics, 56, 177-180. 
19. Kloepper, J.W.; Rodriguez-Kabana, R.; McInroy, J.A.; Young, R.W. (1992). Rhizosphere bacteria antagonistic to soybean cyst (Heterodera glycines) and root-knot (Meloidogyne incognita) nematodes-identification by fatty acid analysis and frequency of biological control activity. Plant Soil, 139, 75-84

20. Kremer, R.J.; Kennedy, A.C. (1996). Rhizobacteria as biocontrol agents of weeds. Weed Technol., 10, 601-609.

21. Loper, J.E.; Schroth, M.N. (1986). Influence of bacteria sources of Indole-3-acetic acid on root elongation of sugarbeet. Phytopathol., 76, 386-389.

22. Mazzola, M.; Stahlman, P.W.; Leach, J.E. (1995). Application method affects the distribution and efficacy of rhizobacteria suppressive of Downy Brome (Bromus tectorum). Soil Biol. Biochem., 27, 1271-1278

23. McFayden, R.E.C. (1998). Biological control of weeds. Ann. Rev. Entomol., 43, 369-393.

24. Paoletti, M.G.; Pimentel, D. (2000). Environmental risks of pesticides versus genetic engineering for agricultural pest control. $J$. Agr. Environ. Ethics, 12, 279-303.

25. Park, M.; Kim, C.; Yang, J.; Lee, H.; Shin, W.; Kim, S.; Sa, T. (2005). Isolation and characterization of diazotrophic growth promoting bacteria from rhizosphere of agricultural crops of Korea. Microbiol. Res., 160, 127-133.

26. Pasqual, M. (2001). Meios de cultura, cultura de tecidos: tecnologia $e$ aplicações. UFLA/FAEPE, Lavras, 74p.

27. Scott, A.J.; Knott, M. (1974). Cluster analysis method for grouping means in the analysis of variance. Biometrics, 30, 507-512.
28. Shriner, R.L.; Fuson, R.C.; Curtin, D.Y.; Morrill, T.C. (1983). Identificação Sistemática dos Compostos Orgânicos. $6^{a}$ Edição. Editora Guanabara Dois, Rio de Janeiro, 520p.

29. Slininger, P.J.; Burkhead, K.D.; Schisler, D.A. (2004). Antifungal and sprout regulatory bioactivities of phenylacetic acid, indole-3acetic acid, and tyrosol isolated from the potato dry rot suppressive bacterium Enterobacter cloacae S11:T:07. J. Industrial Microbiol. Biotechnol., 31, 517-524.

30. Souza, L.S.; Losasso, P.H.L.; Oshiiwa, M.; Garcia, R.R.; Goes Filho, L.A. (2006). Efeitos das faixas de controle do capim-braquiária (brachiaria decumbens) no desenvolvimento inicial e na produtividade do cafeeiro (coffea arabica). Planta Daninha, 24, 715-720.

31. Stonard, R.J.; Miller-Wideman, M.A. (1994). Herbicides and Plant Growth Regulators, In: Godfrey, C.R.A. Agrochemicals from Natural Products. Marcel Dekker, New York, p.215-255.

32. Suckstorff, I.; Berg, G. (2003). Evidence for dose-dependent effects on plant growth by Stenotrophomonas strains from different origins. J. Appl. Microbiol., 95, 656-663.

33. Zaidi, S.; Usmani, S.; Singh, B.R.; Musarrat, J. (2006). Signi.cance of Bacillus subtilis strain SJ-101 as a bioinoculant for concurrent plant growth promotion and nickel accumulation in Brassica juncea. Chemosphere, 64, 991-997.

34. Zehnder, G.W.; Yao, C.B.; Murphy, J.F.; Sikora, E.R.; Kloepper, J.W (2000). Induction of resistance in tomato against cucumber mosaic cucumovirus by plant growth-promoting rhizobacteria. Biocontrol., $45,127-137$. 